\title{
Importance of nutrition and lifestyle for elderly during the COVID-19 pandemic
}

\author{
Nugroho Abikusno \\ Departemen Ilmu Gizi, Fakultas Kedokteran Universitas Trisakti, Indonesia \\ Email: n_nabikusno@trisakti.ac.id
}

Presently the world is experiencing a pandemic of a global magnitude never before witnessed and recorded by human civilization. No one is excluded from this disease and the most vulnerable are the very young and/the very old in our population. It is the most highly communicable and severe viral infection and most of our reproductive age population show practically no signs or symptoms of infection unless they are tested positive using the PCR method or arrive at the hospital in acute respiratory distress. ${ }^{(1)}$ The infection spreads mostly in: 1) closed environment with poor ventilation such as clubs, café, restaurants, meeting rooms; 2) among crowds of people such as in public stations, malls, religious gatherings and cinemas as well as; 3) within close contact with people usually friends, family or co-workers who form the cluster most likely to be infected with the virus. ${ }^{(2)}$

The first case was reported in Wuhan China as early as November 2019 and by August $16^{\text {th }}, 2020$ had spread in China (89.761), US ( $>5.25$ million), India ( $>2.5$ million) and Indonesia (137.468) to name a few in the Asia Pacific region affected by this pandemic. ${ }^{(3,4)}$ The first stage of preventing further outbreaks of this disease is implementation of lock down in areas where cases were reported and traced in each vicinity. People were advised to adhere to health protocols such as: 1) using masks; 2) physical distancing of at least 1 meter, and; 3) hand washing with soap. ${ }^{(5)}$

In public transportation customer seating conformed to the one-meter distancing between each customer and occupancy decreased by at least 50 percent. When people entered public facilities, they were tested for body temperature not to exceed 37.4 degrees centigrade and required to wash their hands with sanitizer before entering public facilities. This rule is also adapted to the use of ATM machines.

After 4 months, due to the threat of economic recession where most countries began to experience lowering of economic growth rate and unemployment, the lock down was periodically lifted. Initially, essential workers such as health personnel, security, essential government public service providers, were those allowed to continue work outside of home but must strictly comply to both personal health protocol and the 3Cs in their respective environment. However, what happened eventually was the rise again of positive cases and active clusters due to the lack of discipline in performing the recommended health protocol or simply a feeling of euphoria of people being in-house for 4 months lock down and suddenly they were able to meet and socialize (usually by unmasking or using improper masks) with their friends, family and co-workers outside of home. Thus, in the future everyone has to adopt to a new way of life (aka new normalcy or life style) using the present health protocol and in strict observance of the $3 \mathrm{Cs}$ in the surrounding working or living environment. ${ }^{(6)}$ Even though by 2021 a vaccine will be available will not guarantee uninfected with COVID-19 due to the possibility of viral gene mutations such as $\mathrm{D} 614 \mathrm{G}$ and people not strictly complying with the new lifestyle as mentioned above. ${ }^{(7)}$

Those who are most severely affected by the pandemic are the very young and the very old so many restrictions had to do with consistent compliance with health protocol and the 3Cs. This policy gave special focus on these vulnerable groups in home isolation and recommended only necessary errands to be performed near their immediate environment with limited safe contact of 5 minutes which are still mandatory for these age groups. In most cases remote learning in the form of zoom meetings or webinars will become the mode of the future for information gathering, learning, use of artificial intelligence for online health consultations, and selling of products in order to control the disease and revive the local economy.

At this moment in Indonesia the number of positive cases of COVID-19 is over 275.000 cases 
with over 10.000 deaths (national task force, $27^{\text {th }}$ September 2020) the majority are males in middle age and above. ${ }^{(8)}$ During PCR testing in positive case clusters most cases are clinically symptomless in young adults. However if the are in contact with family or office members in their cluster those who are identified as COVID-19 positive will have quadrupled in number. Thus, it is imperative to strictly comply with the health protocol (aka as $3 \mathrm{M}$ local abbreviation of maintaining physical distancing, washing hands and wearing masks).

As mentioned before most positive cases and fatality are in the middle age group including elderly. Older persons are more vulnerable because they harbour multi-pathologies such as hypertension, diabetes and if left unattended will lead to heart disease and other severe complications such as acute respiratory distress. Besides the elderly are often left alone at home in social isolation and other psychosocial/mental health disorders could arise such as loneliness, depression that may lead to dementia and suicide. Mentally older people are faced with fear, unhappiness and anxiety. Thus, in order to control or prevent this situation prevailing in older persons nutrition to improve their immune state as well as exhibiting health lifestyle are most important to prevent both biological disease as well as psychosocial disorders.

Maintaining health state of older persons during home isolation focuses on COVID-19 prevention. If any member including older persons experience flu-like symptoms then those who are sick and especially immunocompromised should wear proper masks, wash hands regularly and maintain physical distancing of 1-2 meters from other family members. Masks preferably are surgical-type and cover the lower part of the nose to the lower jaw surface. Those masks made of cloth should be multi-layered. If their symptoms get worse such as running high fever and difficulty in breathing, the family should call and report the case to the local COVID-19 hotline service for further medical referral.

For other family members standard health protocol should be observed including washing hands with soap after returning home from doing outside activities. Regular daily exercise could be done at home or outside; it is especially important to get ultraviolet (UV) sunlight exposure between 7 to $9 \mathrm{AM}$ in the morning. This is most important for older persons to receive direct sunlight exposure because it improves vitamin $\mathrm{D}$ metabolism important for bone metabolism, improves their mobility, balance and flexibility, as well as increase good cholesterol (HDL-lipoprotein) in the blood circulation. ${ }^{(9)}$ Early morning flexibility and meditation exercise is recommended to be performed immediately after waking up in the morning and/just before having a morning bath. Older persons should have enough sleep especially in the night and before sunrise between 9 PM to 3 $\mathrm{AM}$ in the early morning.

Maintaining nutrition state of older persons should observe the following: 1) eat regularly small portion of meals but eat frequently (4-5x daily); 2) focus on compound carbohydrates rich in fiber and avoid foods containing refined sugar; 3) protein intake in older persons is most necessary between $0.8-1.2$ grams $/ \mathrm{kg}$ body weight in terms of household measures equivalent to 1 chicken egg, 2 medium slices of tempeh or 1 small slice of meat; 4) high portions of green leafy vegetables and/ multi-color fruits should be consumed in every meal and/ snacks (4-5x daily); 5) yogurt is advised to be consumed 2x daily (morning \& evening); 6) consume plenty of fluids (water or green/chai tea) 2.5 liters daily (7-8 medium size glasses spread during the day); 7) preparation of meals greatly depends on older persons food habits and are difficult to change but can be slowly modified; in this case avoid fried foods and focus on dishes rich in spices such as lemon, curry, garlic, and ginger to increase immunity. For those having difficulty in eating who are frail or suffering from dementia milk at least 1-2 cups daily would be ideal preferably that are low in fat, high in calcium, and contain whey protein good to be given to older persons with sarcopenia. ${ }^{(10)}$

Common problems encountered by older persons food consumption are: 1) poor dental health such as tooth loss and poor dentures in this case more liquid to soft foods are advised; 2) poor immune system especially those who are frail and sarcopenic can consume fluid and soft foods such as eggs, yogurt, and milk given to increase daily protein intake; 3 ) inadequate intake of micro nutrients vitamins A, B especially folic acid and niacin, $\mathrm{C}, \mathrm{D}$, and $\mathrm{E}$ are given as mixed veggies and fruit smoothies or in the form of multi-vitamin supplements.

Signs of older persons requiring special nutrition intervention are; 1) those who are frail require protein to retain muscle mass in sarcopenia; 2) poor dental health inhibit the capacity to digest foods so affordable artificial dentures are needed or feeding fluid and/soft foods are given to older persons who are not obsessed with food form, 
texture and aroma; 3 ) in the case of poor immune system usually these older persons have difficulty in food intake because of appetite loss that leads to food avoidance which require special attention and approach to maintain their optimal nutrition state and; 4) prevalent in older persons are micronutrient deficiencies as stated above which require daily nutrition supplementation.

In cases such as dementia their food preferences in terms of their likes and dislikes will change as dementia progresses in severity. Thus, the amount and variety of food is affected in older persons with dementia. Eating using utensils and drinking from glasses become more difficult because of coordination problems. Studies have shown interventions that help increase food and fluid intake in dementia are by: 1) caregivers role in assisting in older person with dementia eating their meals; 2) provision of nutritional supplements such as multivitamins, omega-3 capsules for improving brain cell membrane and signal transmission networks; 3) managing swallowing problems experienced by older persons with dementia; 4) food preparation that focus on appearance and attractiveness to increase appetite of older persons; 5) creating an optimal eating environment for older persons such as avoiding eating alone and eating with loved ones, close friends or extended family members. ${ }^{(11,12)}$

Signs of food dislike in older persons with dementia are: 1) they refuse the food or spit food out; 2) they may dislike food and attempt to communicate it to caregiver such as food is too hot or not sure about what to do with the food in their mouth; 3) indifference to food are shown by turning away or not willing to open their mouth, spitting the food, and coughing or choking; and 4) in the above cases the caregiver should stop and respect their actions.

In general, improving meals for elderly can be done by; 1) making meals nutrient dense so focus on quality and not quantity of foods; 2 ) adding extra calories without extra volume of food; 3) use herbs and spices when preparing meals to increase appetite while providing food sources to improve their immunity; 4) make meals more colorful and appealing to attract food appetite; 5) serve frequent small meals and snacks to cause hunger in the older persons; 6) do not fill up their food consumption with non-nutritious foods items that are mostly high in trans fatty acids, sugars, and salts in packaged or manufactured foods so present fresh and naturally prepared food meals; and finally 7) make meal time enjoyable and a social affair for the older person.

\section{REFERENCES}

1. Passcarella G, Strumia A, Piliego C, et al. COVID-19 diagnosis and management: a comprehensive review. J Intern Med. 2020 Aug;288(2):192-206. doi: 10.1111/joim.13091

2. Furuse Y, Sando E, Tsuchiya N, et al. Clusters of Coronavirus Disease in Communities, Japan, January-April 2020. Emerg Infect Dis. 2020 Sep; 26(9): 2176-2179. doi: 10.3201/eid2609.202272

3. Wu YC, Chen CS, ChanYJ. The outbreak of COVID-19: An overview. J Chin Med Assoc. 2020 Mar; 83(3): 217-220. Published online 2020 Feb 12. doi: 10.1097/JCMA.0000000000000270

4. World Health Organization. Coronavirus Disease (COVID-19): Situation Report - 209, 16 August 2020 [Internet]. World Health Organization; 2020. Available from: https:/www.who.int/docs/defaultsource/coronaviruse/situation-reports/20200816covid-19-sitrep-209.pdf?sfvrsn=5dde1 ca2_2

5. Chu DK, Akl EA, Duda S, et al. Physical distancing, face masks, and eye protection to prevent personto-person transmission of SARS-CoV-2 and COVID-19: a systematic review and meta-analysis. Lancet. 2020 Jun 27;395(10242):1973-1987. doi: 10.1016/S0140-6736(20)31142-9.

6. Gugus Tugas Percepatan Penanganan COVID-19. Standar Alat Pelindung Diri (APD) untuk Penanganan COVID-19 di Indonesia [Internet]. 3rd rev. Jakarta: Gugus Tugas Percepatan Penanganan COVID-19; 2020 [updated 2020 Aug; cited 2020 Aug 11]. 42 p. Available from: https://covid19. go.id/storage/app/media/Materi\%20Edukasi/ standar-apd-revisi-3.pdf

7. Korber B, Fischer WM, Gnanakaran S, et al. Tracking Changes in SARS-CoV-2 Spike: Evidence that D614G Increases Infectivity of the COVID-19 Virus. Cell. 2020 Aug 20;182(4):812827.e19. doi: $10.1016 /$ j.cell.2020.06.043

8. Kemenkes RI. Situasi Terkini Perkembangan Coronavirus Disease (COVID-19) 28 September 2020 [Internet]. Jakarta: Kemenkes RI; 2020 [cited 2020 Sep 27]. Available from: https://covid19.kemkes.go.id/situasi-infeksiemerging/info-corona-virus/situasi-terkiniperkembangan-coronavirus-disease-covid-19-28september-2020/\#.X7jAeWgzY2x

9. Patwardhan VG, Khadilkar AV, Chiplonkar SA, et al. Varying relationship between 25-hydroxyvitamin D, high density lipoprotein cholesterol, and serum 7-dehydrocholesterol reductase with sunlight exposure. J Clin Lipidol. 2015 SepOct;9(5):652-7. doi: 10.1016/j.jacl.2015.05.007

10. Camargo LDR, Doneda D, Oliveira VR. Whey protein ingestion in elderly diet and the association with physical, performance and clinical outcomes. Exp Gerontol. 2020 Aug;137:110936. doi: 10.1016/j.exger.2020.110936

11. Godos J, Currenti W, Angelino D, et al. Diet and Mental Health: Review of the Recent Updates on Molecular Mechanisms. Antioxidants (Basel). 2020 Apr 23;9(4):346. doi: 10.3390/antiox9040346

12. Bae JH, Kim G. Systematic review and metaanalysis of omega-3-fatty acids in elderly patients with depression. Nutr Res. 2018 Feb;50:1-9. doi: 10.1016/j.nutres.2017.10.013 